\title{
Mechanism of Roof Shock in Longwall Coal Mining under Surface Gully
}

\author{
Gangwei Fan, Dongsheng Zhang, and Xufeng Wang \\ School of Mines, Key Laboratory of Deep Coal Resource Mining, Ministry of Education of China, \\ China University of Mining \& Technology, Xuzhou 221116, China
}

Correspondence should be addressed to Dongsheng Zhang; zdscumt@126.com

Received 10 November 2014; Revised 21 February 2015; Accepted 23 February 2015

Academic Editor: Shimin Liu

Copyright (C) 2015 Gangwei Fan et al. This is an open access article distributed under the Creative Commons Attribution License, which permits unrestricted use, distribution, and reproduction in any medium, provided the original work is properly cited.

The paper presents an interpretation on the abnormal roof shock in longwall coal mining under gullies using physical modeling, numerical modeling, and mechanical analysis. The modeling results show that the roof movement causes the shock load onto the stope in longwall coal mining under surface gully. The triggering mechanism of shock load depends on the direction of the face retreat with respect to the bottom of the surface gully. The slope tends to slide along the interface plane with a long periodical weighting intervals when mining towards the bottom of the gully (downslope direction), while the overburden strata may be split into blocks and tend to topple towards the free face of gully when mining away from the bottom of the gully (upslope direction). The mechanical models showed that, during the period of mining in downslope direction, planar sliding and key fragmental blocks cause a sudden roof shearing off which could result in shock load and, during the period of mining in upslope direction, the overburden blocks may become unstable due to shearing off which could resulted in large shock pressure onto the stope.

\section{Introduction}

With the development of coal mining technology and equipment in China, the mining scale becomes larger and larger. And the center of coal resource exploitation has transferred to western coalfield, where there is rich coal resource $[1,2]$. The coal is shallow, thick, and excellent in quality. For example, Shenfu-Dongsheng coalfield with 223.6 billion tons coal in proved reserves is the biggest coalfield in China and one of seven biggest coalfields in the world [3]. However, the ground surface is bare and has been subjected to serious water erosion for long time, resulting in that wide spread of surface gullies, especially in Northwest of China. The gully depth may exceed $100 \mathrm{~m}$.

Abnormal phenomena such as coal bump and roof shock are observed in shallow longwalls under gullies. In Dongsheng coalfield, sudden spalling of barrier pillars and crushing of face hydraulic supports without warning frequently occurred in underground stopes (see Figure 1). These events cannot be explained according to traditional theories on coal mine ground pressure [4-6]. In general, coal and/or rock bump usually occurs in deep coal mining due to the super-high ground pressure [5-7]. As the mining depth in this region is less than $200 \mathrm{~m}$, the absolute ground pressure is not great enough to trigger a coal or rock bump. It is found that most of these dynamic events are involved in coal mines operated under surface gullies. Therefore, the slope movement of gullies is thought of as an additional factor resulting in the abnormal underground pressure.

Many researchers studied the influence of underground mining on surface slope [8-15]. It is accepted that underground mining may cause surface slope sliding or even geological disaster. The effect of surface topography on underground mining was rarely taken into consideration in the previous researches, but it is sensitive and strong and, at times, can play a dominant role on ground pressure in shallow coal seam mining under surface gully. Therefore, it is very urgent and important to clearly understand the mininginduced roof shock in gully areas.

\section{Mechanisms of Overburden Movement}

Based on the geological condition of Houhayewusu Gully at Nalinmiao number 2 Coal Mine, physical simulation and numerical modeling were conducted to analyze the effect of 


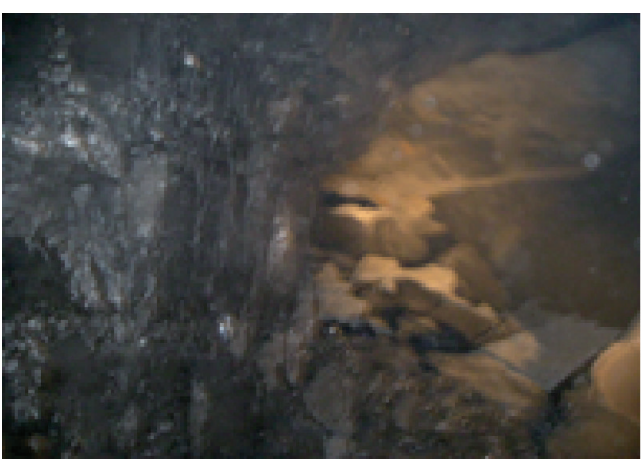

(a)

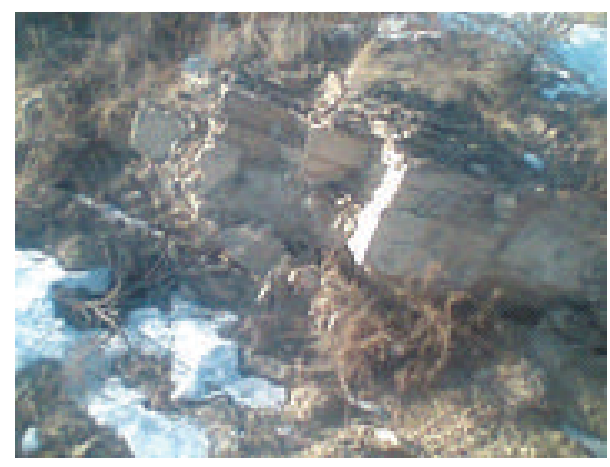

(b)

FIGURE 1: The abnormal phenomena in underground mining under gullies. (a) Pillar gets inclined and spalls; (b) slope rock is broken and bare.

TABLE 1: Key properties of the overlying rock.

\begin{tabular}{|c|c|c|c|c|c|c|}
\hline Lithology & $\begin{array}{c}\text { Thickness } \\
/ \mathrm{m}\end{array}$ & $\begin{array}{l}\text { Density } \\
/ \mathrm{kg} \cdot \mathrm{m}^{-3}\end{array}$ & $\begin{array}{c}\text { Young's modulus } \\
\text { /GPa }\end{array}$ & $\begin{array}{c}\text { Cohesion } \\
/ \mathrm{MPa}\end{array}$ & $\begin{array}{c}\text { Friction angle } \\
/^{\circ} \\
\end{array}$ & Poisson's ratio \\
\hline Loess & 10 & 1810 & - & - & - & - \\
\hline Mudstone & 3.5 & 2500 & 15 & 1.5 & 30 & 0.3 \\
\hline Fine sandstone & 8 & 2600 & 35 & 2.2 & 33 & 0.2 \\
\hline Sandy mudstone & 11 & 2510 & 16 & 1.8 & 32 & 0.25 \\
\hline Fine sandstone & 12 & 2545 & 23 & 2.1 & 34 & 0.22 \\
\hline Sandy mudstone & 9 & 2510 & 16 & 1.6 & 32 & 0.25 \\
\hline Fine sandstone & 20 & 2600 & 38 & 2.6 & 35 & 0.2 \\
\hline Sandy mudstone & 2.5 & 2510 & 16 & 1.6 & 32 & 0.25 \\
\hline Fine sandstone & 8 & 2600 & 38 & 2.6 & 35 & 0.2 \\
\hline Sandy mudstone & 0.5 & 2510 & 16 & 1.6 & 32 & 0.25 \\
\hline Coal & 6.5 & 1370 & 39 & 2.3 & 34 & 0.23 \\
\hline Siltstone & 4 & 2580 & 42 & 2.6 & 36 & 0.22 \\
\hline
\end{tabular}

underground coal mining on the overburden movement at gully area.

2.1. Geology. The coal measure is mainly as Jurassic formations which is covered with Quaternary unconsolidated layers. The coal seam is $6.5 \mathrm{~m}$ thick and the overlying bedrock is $74.5 \mathrm{~m}$ thick. A 10 -meter-thick loess overlays the bedrock. The maximum depth of gully is $73.5 \mathrm{~m}$ and the average slope of gully is $30^{\circ}$ (see Figure 2). The generalized stratigraphy at the studied area is shown in Figure 3. The overlying bedrock is predominantly composed of fine sandstone and sandy mudstone, and most of them are involved in the gully. The properties of overlying strata are shown in Table 1.

2.2. Physical Simulation. Physical modeling is a scale modeling in which rock strata and mine structures are simulated using scaled artificial materials. Physical simulation can realistically model the layered structures and their failure modes, much like that observed in underground coal mines, and strata movement can be observed directly in real time [5].

2.2.1. Model Setup. Simulated material selection is of great importance for modeling the mining-induced overburden

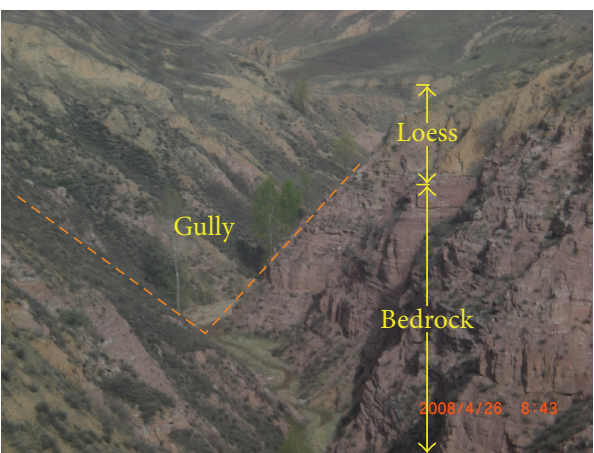

FIGURE 2: A photo of Houhayewusu Gully at underground mining area.

movement. The material is always mixed by the aggregate and the adhesive. Sand is generally used as the aggregate. The most popular materials used as the adhesives are gypsum, cement, calcium carbonate $\left(\mathrm{CaCO}_{3}\right)$, lime, and kaolin [16]. In this paper, sand, gypsum, and calcium carbonate were selected as the mixed materials in some given proportions. According to the widely accepted results on the mix proportions among sand, gypsum, and calcium carbonate [16], the mix design of 


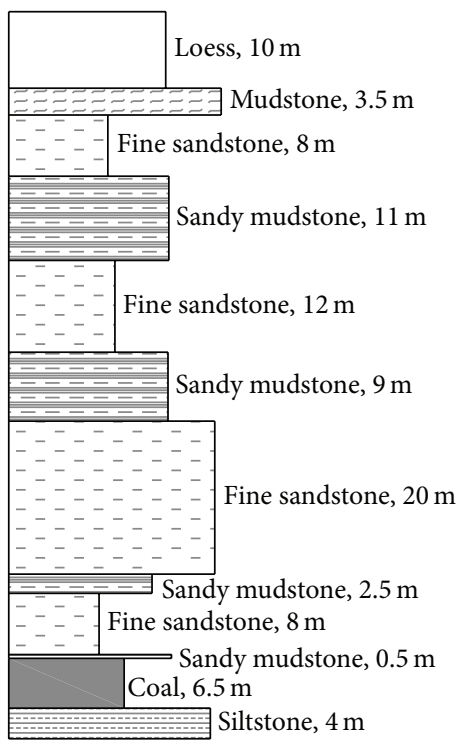

FIGURE 3: Generalized geological column at studied area.

TABLE 2: The mix proportion of simulated materials.

\begin{tabular}{lccccc}
\hline Lithology & $\begin{array}{c}\text { Sand } \\
/ \mathrm{kg}\end{array}$ & $\begin{array}{c}\mathrm{CaCO}_{3} \\
/ \mathrm{kg}\end{array}$ & $\begin{array}{c}\text { Gypsum } \\
/ \mathrm{kg}\end{array}$ & $\begin{array}{c}\text { Water } \\
/ \mathrm{kg}\end{array}$ & $\begin{array}{c}\text { Sawdust } \\
/ \mathrm{kg}\end{array}$ \\
\hline Loess & 95.8 & 6.8 & 6.8 & 18.8 & 3.4 \\
Mudstone & 44.6 & 5.2 & 2.2 & 6.5 & $/$ \\
Fine sandstone & 105.8 & 10.6 & 10.6 & 15.9 & $/$ \\
Sandy mudstone & 160.4 & 22.5 & 9.6 & 24.1 & $/$ \\
Fine sandstone & 175.3 & 40.9 & 17.5 & 33.4 & $/$ \\
Sandy mudstone & 159.6 & 22.3 & 9.6 & 23.9 & $/$ \\
Fine sandstone & 356.7 & 59.4 & 59.4 & 67.9 & $/$ \\
Sandy mudstone & 53.1 & 7.4 & 3.2 & 8.0 & $/$ \\
Fine sandstone & 153.0 & 25.5 & 25.5 & 29.1 & $/$ \\
Sandy mudstone & 10.6 & 1.5 & 0.6 & 1.6 & $/$ \\
Coal & 138.1 & 19.3 & 8.3 & 20.7 & $/$ \\
Siltstone & 76.5 & 12.8 & 12.8 & 14.6 & $/$ \\
\hline
\end{tabular}

different layers is listed in Table 2. Wood sawdust was mixed with the above three materials to simulate loess material.

The geometric scale $\left(\alpha_{l}\right)$ of this model is defined as 1:100 to the real. The gully is shaped like " $\mathrm{V}$ " in the model. The model frame is $5 \mathrm{~m}$ long, $0.3 \mathrm{~m}$ wide, and $0.95 \mathrm{~m}$ high. The slope angle of gully is $30^{\circ} .5 \mathrm{~cm} \times 5 \mathrm{~cm}$ grid was painted on the surface of model (see Figure 4). According to the scale model theory, the similarity scale of gravity $\left(\alpha_{\gamma}\right)$ is about $1: 1.67$, and the similarity scale of stress $\alpha_{s}=\alpha_{l} \times \alpha_{\gamma}=1: 167$. The excavation was conducted from the left to the right. The mining height is $6.5 \mathrm{~cm}$ and the excavation web is $5 \mathrm{~cm}$. The total mining void is $420 \mathrm{~cm}$ long.

2.2.2. Modeling Result. The physical modeling was conducted in two stages (see Figure 4).

(1) Downslope stage, in which the coalface is advancing in the downslope direction and the gob is getting close with the bottom gully. Typical overburden movement was observed until the coalface is located underneath the slope. Figure 5 shows some scenes of overburden movement in downslope mining stage. When the coalface was at $160 \mathrm{~m}$ away from the setup line, a downward crack appeared at the surface. Meanwhile, the overlying slope subsided and slipped towards gully due to lack of horizontal confinement. The interfaces were seriously broken with significant planar sliding. The roof breakage interval became longer, which may result in a roof shock in underground if the roof suddenly collapses down (see Figure 5(a)). When the coalface approached the bottom of the gully, the roof sheared off along the coalface (see Figure 5(b)), which may also initiate a shock load onto the face support.

(2) Upslope stage, in which the coalface is advancing in the upslope direction away from the gully. After the coalface passed the bottom of the gully and moved away from the gully, a crack linking the slope with the gob developed in the roof. Figure 6 shows a scene of overburden movement in upslope mining stage. The broken roof was cut into blocks by gully and mining-induced cracks. The formed blocks rotated towards the gob, and sometimes it is hinged above the retreating face. However, the hinged structure lost the stability in a short time as the broken block sheared off along the hinged point, which may also trigger a roof shock onto the face hydraulic support.

2.3. Numerical Modeling. FLAC (Fast Lagrangian Analysis of Continua) software was used to analyze the mechanism of slope movement. The constructed numerical model was shown in Figure 7. The geological column is based on the generalized stratigraphy shown in Figure 3. The Mohr-Coulomb criterion was employed to estimate the failure of rocks. The physical and mechanical parameters of the overlying strata used in FLAC model are listed in Table 1. The left, the right, and the bottom boundaries of the model are fixed, and the top boundary is free.

2.3.1. Model Calibration. The mechanical behavior of caved zone (gob) greatly affects the overburden movement. An appropriate gob model is crucial to analyze the mechanical mechanism of slope deformation in response to underground mining. Salamon's model developed by Salamon is useful to understand the compaction characteristics of caved rock in gob [17], which is widely accepted by many researchers [5]. Salamon's model assumes the following strain hardening model for gob material:

$$
\begin{gathered}
\sigma=\frac{E_{0} \varepsilon}{1-\varepsilon / \varepsilon_{m}}, \\
\varepsilon_{m}=\frac{b-1}{b}, \\
E_{0}=\frac{10.39 \sigma_{c}^{1.042}}{b^{7.7}},
\end{gathered}
$$




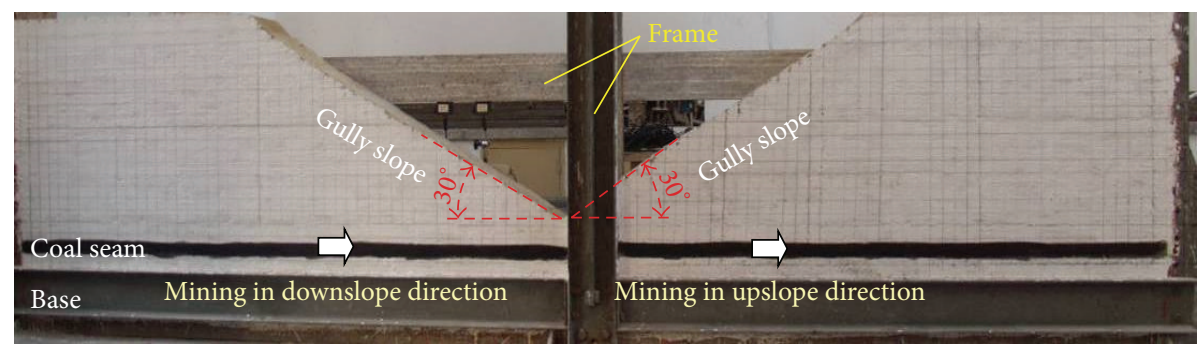

FIGURE 4: The original model for the physical experiment.

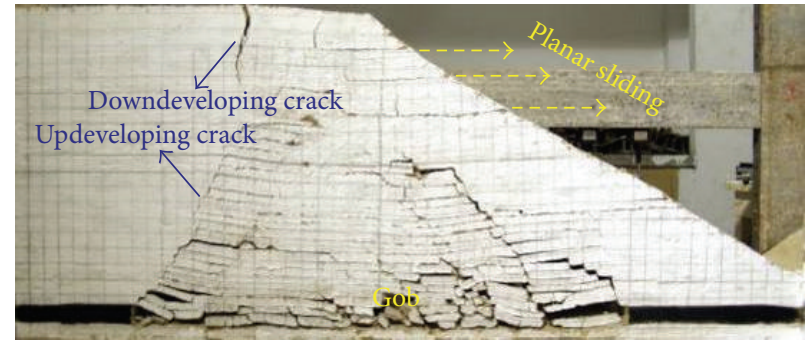

(a)

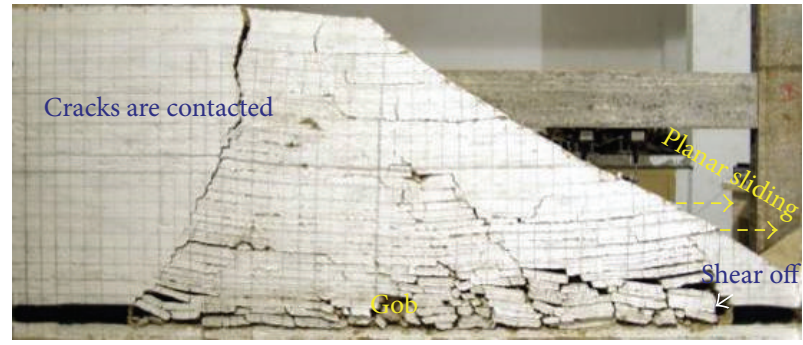

(b)

FIGURE 5: The overburden movement in response to underground mining in downslope direction. (a) The slope slid obviously layer by layer. (b) The roof sheared off along the coalface.

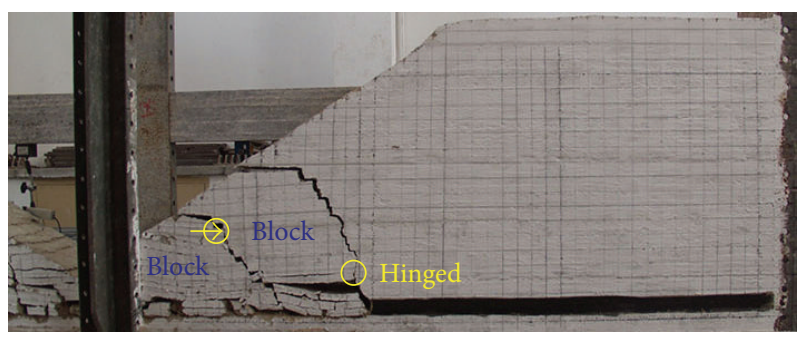

FIGURE 6: The overburden movement in response to underground mining in upslope direction.

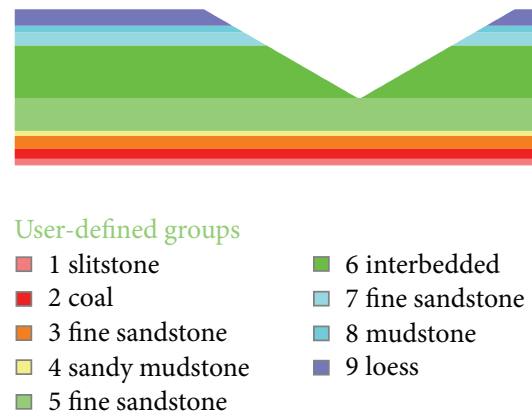

FIGURE 7: The model for FLAC modeling.

where $b$ is the bulking factor, $\varepsilon_{0}$ is the compaction strain, and $E_{0}$ is the initial gob modulus.

However, there is no ready-made model for Salamon's model in FLAC. Double yield material model was selected to simulate Salamon's model. A process of trial and error is used to match the stress-strain curve of Salamon's model to that of the double yield model [5], resulting in a set of input parameters for converting Salamon's model to the double yield model (Tables 3 and 4 ).

Figure 8 shows the stress-strain behavior of a simple cube gob model of $10 \mathrm{~cm}$ thick loaded at the top at a constant velocity using the input data listed in Tables 3 and 4 . It shows a good match between the results of FLAC simulation and Salamon's model.

2.3.2. Modeling Result. Downslope stage: the distribution of equivalent plastic stain in the overlying strata was plotted in Figure 9(a) to analyze the fracture development. The fractures in the overlying strata developed upward from the gob, while the surface fractures extended downward. When the coalface was at $42 \mathrm{~m}$ away from the bottom of the gully, shear failure was observed at the slope of the gully associated with horizontal slippage at the bedding planes. When the coalface was at $12 \mathrm{~m}$ away from the bottom of the gully, the upward and downward fractures became connected and the fractures at bedding planes reached the slope of the gully. When the coalface was $6 \mathrm{~m}$ away from the bottom of gully, the overlying strata sheared off along the face line.

Upslope stage: after the coalface passed the gully, the overburden moved in different patterns (see Figure 9(b)). When the coalface advanced at $36 \mathrm{~m}$ away from the gully, most of rock overlying the coalface was fractured and yields in tension or shear. The angle between the fractured rock and the horizontal line is less than $20^{\circ}$. When the coalface is at $60 \mathrm{~m}$ away from the gully bottom, the overlying strata are split into polygons by a fractured zone which connects the slope surface with the coalface. The same phenomena repeated in every face retreat in the upslope stage. 
TABLE 3: Input parameters for the double yield model.

\begin{tabular}{lccccc}
\hline Property & Density, $\mathrm{kg} / \mathrm{m}^{3}$ & Shear modulus, $\mathrm{Pa}$ & Bulk modulus, $\mathrm{Pa}$ & Friction angle, $^{\circ}$ & Dilation angle, $^{\circ}$ \\
\hline Value & 2410 & $1.19 e 10$ & $1.35 e 10$ & 10 & 5 \\
\hline
\end{tabular}

TABLE 4: Volumetric strain-hydrostatic pressure relationship of the gob material.

\begin{tabular}{lccc}
\hline Volumetric strain & Hydrostatic pressure, Pa & Volumetric strain & Hydrostatic pressure, Pa \\
\hline 0 & 0 & 0.12 & 17725587.81 \\
0.01 & 711498.289 & 0.13 & 21284942.79 \\
0.02 & 1493364.541 & 0.14 & 25710086.82 \\
0.03 & 2356581.038 & 0.15 & 31360655.35 \\
0.04 & 3314540.81 & 0.16 & 38827478.06 \\
0.05 & 4383747.523 & 0.17 & 49153934.99 \\
0.06 & 5584774.241 & 0.18 & 64371871.52 \\
0.07 & 6943600.091 & 0.19 & 89035423.82 \\
0.08 & 8493510.825 & 0.20 & 135896173.2 \\
0.09 & 10277861.84 & 0.21 & 259438148.8 \\
0.10 & 10277861.84 & 0.22 & 1494857905 \\
0.11 & 14800573.32 & & \\
\hline
\end{tabular}

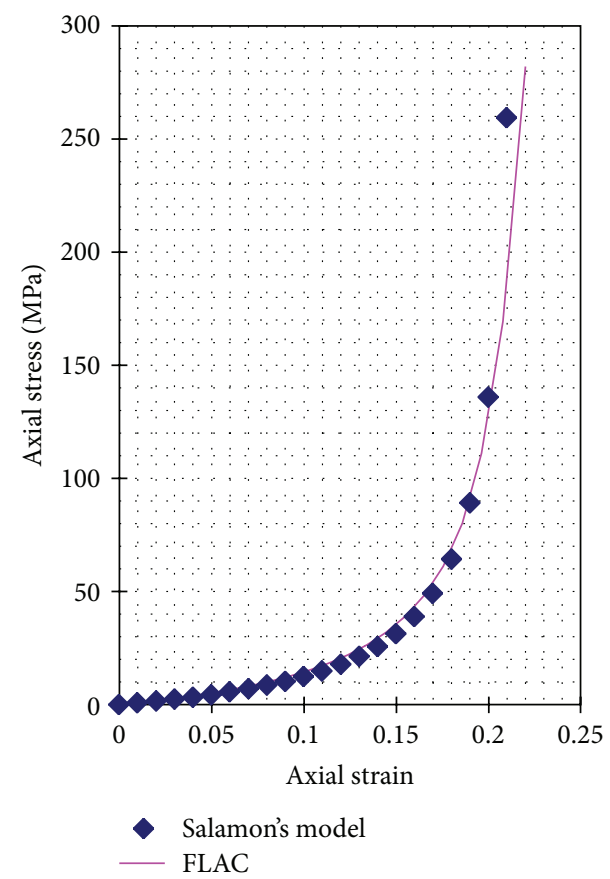

FIGURE 8: Stress-strain curve of the gob model.

\section{Mechanisms and Control of Roof Shock}

The roof shock and coal bump in this case are mainly caused by the sudden loss of roof structural stability. The mechanisms of roof shock can be understood after the mechanical analysis on roof structure.

Downslope stage: the physical and numerical modeling results show that when the coalface becomes underneath the gully, the overlying strata may slide towards the gully along the interface planes, and subsequently, the roof may shear off along the face line. The slope of the gully is considered an additional free surface to the fractured blocks at overburden strata. The fractured zone in the overburden strata can be assumed as a beam which breaks into blocks (A, B, and C, Figure 10(a)) in response to underground mining [18]. Block $\mathrm{B}$ is stable due to the compressive forces applied from blocks $\mathrm{C}$ and A. Block A loses the horizontal confinement from the right side when the compressive force between blocks $\mathrm{A}$ and $B$ is greater than the total shear strength at the upper and the lower interfaces. Block A may slide towards the gully and, hence, block B will lose the stability and shear off at the contact between blocks A and B. Consequently, a roof shock occurs.

In order to calculate the compressive forces, a free body diagram for blocks $\mathrm{B}$ and $\mathrm{C}$ was constructed as shown in Figure $10(\mathrm{~b}) . P_{\mathrm{B}}$ and $P_{\mathrm{C}}$ are the applied forces on blocks $\mathrm{B}$ and $\mathrm{C}$, respectively. $l_{\mathrm{B}}$ and $l_{\mathrm{C}}$ identify the assumed positions of blocks $\mathrm{B}$ and $\mathrm{C}$ where forces $P_{\mathrm{B}}$ and $P_{\mathrm{C}}$ act on the blocks, respectively. $Q_{A}, Q_{B}$ are the shear force at the hinged contacts between blocks. The lengths of blocks $\mathrm{B}$ and $\mathrm{C}$ are the periodical weighting interval, say $l$. $R_{\mathrm{C}}$ is the supporting force of caved rock onto block C. $T$ is the horizontal compressive force between $\mathrm{A}$ and B. $\theta_{\mathrm{B}}$ and $\theta_{\mathrm{C}}$ are the rotation angles of blocks $\mathrm{B}$ and $\mathrm{C}$, respectively. $a$ is the height of contact face between blocks $\mathrm{A}$ and $\mathrm{B}$.

According to the key strata theory [7] and mechanical analysis,

$$
\begin{gathered}
Q_{\mathrm{B}}\left[l \cos \left(\theta_{\mathrm{B}}-\theta_{\mathrm{C}}\right)+h \sin \left(\theta_{\mathrm{B}}-\theta_{\mathrm{C}}\right)+l\right] \\
+T\left[h-a-l\left(\sin \theta_{\mathrm{B}}+\sin \theta_{\mathrm{C}}\right)\right] \\
=P_{\mathrm{B}}\left[l_{\mathrm{B}} \cos \theta_{\mathrm{B}}+\left(h-\frac{a}{2}\right) \sin \theta_{\mathrm{B}}\right] \\
Q_{\mathrm{A}}+Q_{\mathrm{B}}=P_{\mathrm{B}} \\
T l \sin \theta_{\mathrm{C}}=Q_{\mathrm{B}} l,
\end{gathered}
$$

where $h$ means the thickness of the studied roof beam. 

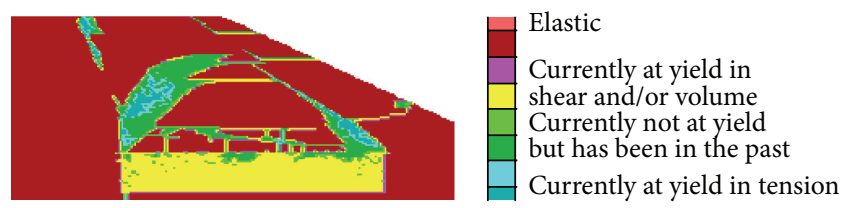

(a) Mining in the downslope direction
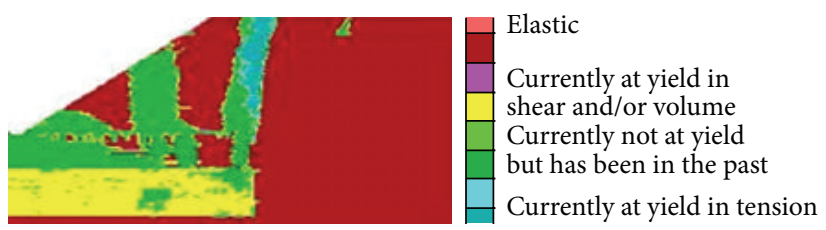

(b) Mining in the upslope direction

FIgURE 9: The failure status when mining under gully.

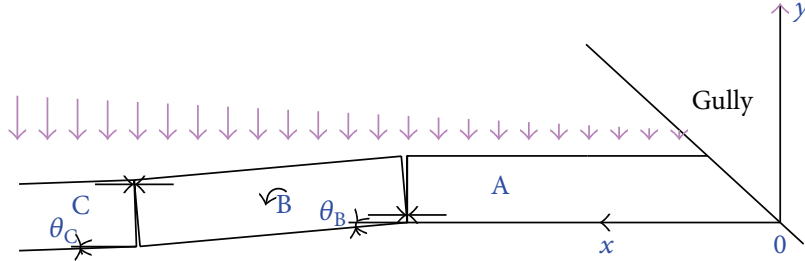

(a)
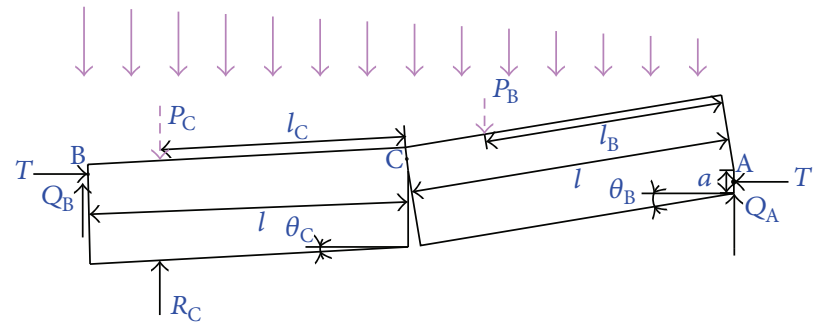

(b)

Figure 10: Mechanical model for roof beam when mining in downslope direction. (a) The assumed mechanical model; (b) mechanical analysis on blocks B and C.

Solving $T$ from (2),

$$
T=P_{\mathrm{B}} \frac{3 L+2 l}{6 L+3 l} \frac{2}{i+2 \sin \left(\theta_{\mathrm{B}} / 4\right)-\sin \theta_{\mathrm{B}}},
$$

where $\sin ^{2}\left(\theta_{\mathrm{B}} / 8\right)$ approximates 0 and is thus omitted; $i$ means the fragmentation degree of the block and is defined by $i=$ $h / l$.

Focusing on block A, the maximum friction force or the shear strength of the interfaces can be estimated by [19]

$$
F=c L+\frac{1}{2} \rho g L^{2} \tan \alpha \tan \varphi,
$$

where $L$ is the length of block A, $c$ is the cohesion of the interfaces, $\rho$ is the density of block A, $g$ is the gravity acceleration, $\alpha$ is the slope angle of gully, and $\varphi$ is the friction angle of the interface.

In order to keep block A out of sliding, the shear strength of the interfaces between the adjacent strata and block A should be greater than the compressive force; then

$$
\begin{aligned}
& \tan \alpha \\
& \leq \frac{2 c L}{2 \rho g l(3 L+2 l) / 3\left(i+2 \sin \left(\theta_{\mathrm{B}} / 4\right)-\sin \theta_{\mathrm{B}}\right)-\rho g L^{2} \tan \varphi} .
\end{aligned}
$$

According to (5), the smaller the gully angle or the rotation degree of block $B$ gets, the less likely block sliding and roof shock occur. Therefore, the block sliding can be controlled by lowering the mining height which will reduce the rotation angle significantly [19].

Upslope stage: the above simulations show that the slope is cut into blocks by large mining-induced cracks and tends to topple when mining in the upslope direction. A hinged structure forms but is less stable. As the face continues to advance, the block may shear off and the structure disappears, which may result in a serious shock in underground.

In order to understand the structure stability, a mechanical model focusing on two key blocks was constructed as Figure 11 shows. $G_{1}$ and $G_{2}$ are the self-gravity of blocks A and $\mathrm{B}$, respectively. $R_{2}$ is the supporting force of caved rock onto block \#2. $\theta$ is the rotation angle of block \#2. a represents the height of the contact between blocks. $Q_{A}, Q_{B}$ are the shear force at the hinged contacts between blocks. $w$ is the subsidence of block \#2. $\alpha$ is the slope angle. $H_{1}, H_{2}$, and $H_{3}$ are the heights of the blocks. $L$ is the length of the blocks.

According to the key strata theory $[7,18]$,

$$
\begin{gathered}
\frac{T}{G_{1}}=\left(\frac{1}{2}-\frac{\tan \alpha}{12 i}\right) \\
\cdot\left((i-\tan \alpha)\left(\frac{1}{2}+\tan \alpha \tan \theta\right)\right. \\
\left.+\left(\frac{1}{\cos \theta}+\frac{\sin \theta}{2}\right)-\sin \theta_{\max }\right)^{-1}, \\
\frac{Q_{\mathrm{A}}}{G_{1}}=1-\frac{\tan \alpha}{\cos \theta} \cdot \frac{T}{G_{1}},
\end{gathered}
$$

where $i$ is the average fragmentation degree of the block and defined by $i=H_{2} / L+(1 / 2) \tan \alpha$.

Block A does not shear off at contact A only if

$$
T \tan \varphi \geq Q_{\mathrm{A}} .
$$




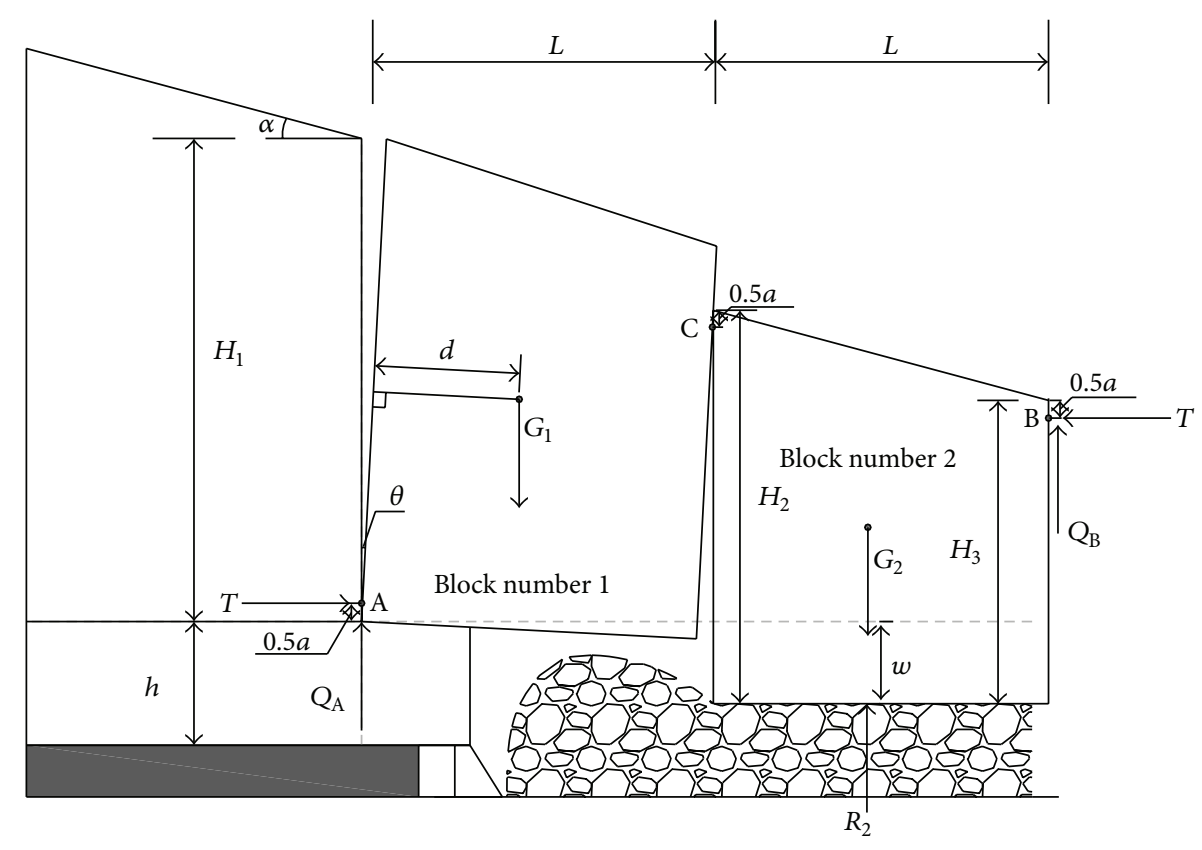

FIGURE 11: Mechanical model for key blocks in upslope mining.

Substituting (6) into (7), then

$$
\begin{aligned}
\frac{Q_{\mathrm{A}}}{T}= & \left((i-\tan \alpha)\left(\frac{1}{2}+\tan \alpha \tan \theta\right)\right. \\
& \left.+\left(\frac{1}{\cos \theta}+\frac{\sin \theta}{2}\right)-\sin \theta_{\max }\right) \\
& \cdot\left(\frac{1}{2}-\frac{\tan \alpha}{12 i}\right)^{-1}-\frac{\tan \alpha}{\cos \theta} \leq \tan \varphi .
\end{aligned}
$$

In order to analyze the block stability, a series of curves showing the relationship between $Q_{\mathrm{A}} / T$ and $\theta$ at different values of $\alpha, \theta_{\max }$, and $i$ were drawn in Figure 12 based on (8). Generally, $\theta_{\max }$ values $8^{\circ}$ to $12^{\circ}, i$ values 0.8 to 1.2 , and $\tan \varphi$ appropriates 0.5 . According to Figure 12 , all the $Q_{\mathrm{A}} / T$ values at the designed conditions are greater than 2 , which means that the blocks may shear off with a large shock load onto the face support. Therefore, a reasonable support capacity is important to control the shock load and the stability of roof blocks.

For the structure to be stable, a reasonable support capacity $R$ must be equal to or greater than the downward transferring loading; that is,

$$
R+T \tan \varphi \geq Q_{\mathrm{A}} .
$$

Substituting (6) into (9),

$$
\begin{aligned}
R \geq[1 & -\left(\left(\frac{1}{2}-\frac{\tan \alpha}{12 i}\right)\left(\tan \varphi+\frac{\tan \alpha}{\cos \theta}\right)\right) \\
& \left((i-\tan \alpha)\left(\frac{1}{2}+\tan \alpha \tan \theta\right)\right. \\
& \left.\left.+\left(\frac{1}{\cos \theta}+\frac{\sin \theta}{2}\right)-\sin \theta_{\max }\right)^{-1}\right] G_{1} .
\end{aligned}
$$

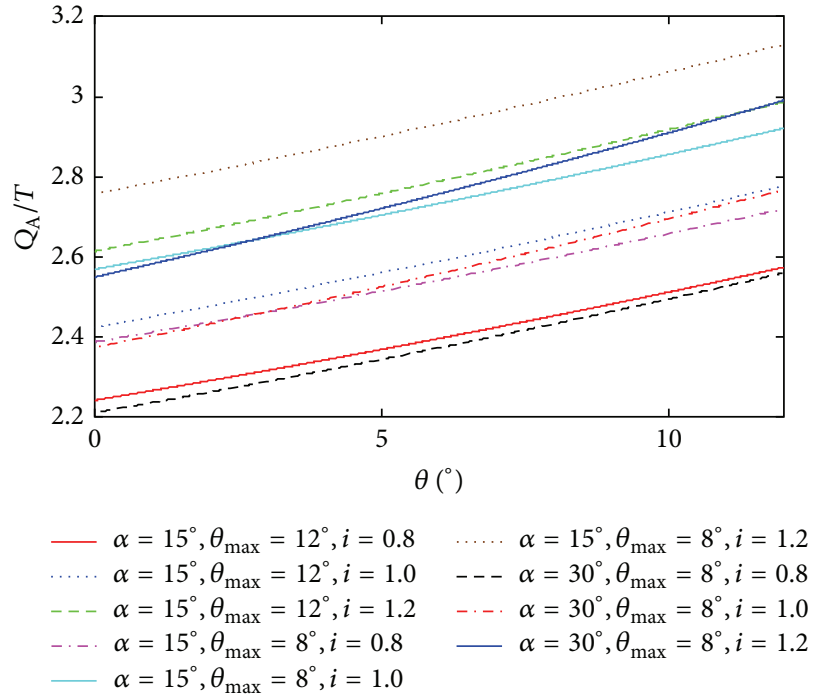

FIgUre 12: Relationship between $Q_{\mathrm{A}} / T$ and $\theta$.

According to (10), the greater the block fragmentation degree or the block rotation angle, the greater the needed support capacity. Based on the definition of block fragmentation degree $i$, the greater the slope angle or the less the block length, the greater the needed support capacity. In other words, if the support capacity cannot meet (10), the block may shear off and roof shock will happen at the coalface, which is hazardous to an underground coal mine. Therefore, strengthening the face support capacity or lowering the mining height may reduce the possibility of roof shock when mining in the upslope direction. 


\section{Conclusions}

The paper presents the modeling results for understanding the mechanisms of roof shock in coal mining under surface gully. Two types of mining directions with respect to the bottom of gully were analyzed: (1) in downslope period where the face retreats towards the bottom of the gully, the slope of gully slid obviously layer by layer due to lack of horizontal confinement, with a resultant roof shearing off; (2) in upslope period, the overlying strata are split into polygon blocks which may suddenly become unstable and shear off with a large shock load onto face support. In order to avoid or control the roof shock in mining under gully, layer sliding should be controlled in downslope period and block shearing off should be avoided in upslope period.

The paper constructs mechanical models to analyze the roof structure stability in response to mining under gully. The mechanical analysis results show that, (1) in downslope period, the smaller the gully angle or the rotation degree of formed blocks gets, the less likely block sliding and roof shock occur; (2) in upslope period, the mining-induced blocks will lose the stability in many scenarios. The roof shock can be controlled by lowering the mining height and strengthening the face support capacity.

\section{Conflict of Interests}

The authors declare that there is no conflict of interests regarding the publication of this paper.

\section{Acknowledgments}

The authors would like to thank the Fundamental Research Funds for the Central Universities (Grant no. 2012QNA35), the National Key Basic Research Program of China (2015CB251600), the National Natural Science Foundation of China (Grant no. 51264035), and the Priority Academic Program Development of Jiangsu Higher Education Institutions (PAPD) for their financial support. Special thanks are given to Dr. Khaled M. Mohamed for language assistance.

\section{References}

[1] G. Fan and D. Zhang, "Mechanisms of aquifer protection in underground coal mining," Mine Water and the Environment, vol. 34, no. 1, pp. 95-104, 2015.

[2] D. Zhang, G. Fan, Y. Liu, and L. Ma, "Field trials of aquifer protection in longwall mining of shallow coal seams in China," International Journal of Rock Mechanics \& Mining Sciences, vol. 47, no. 6, pp. 908-914, 2010.

[3] D. Zhang, G. Fan, L. Ma, and X. F. Wang, "Aquifer protection during longwall mining of shallow coal seams: a case study in the Shendong Coalfield of China," International Journal of Coal Geology, vol. 86, no. 2-3, pp. 190-196, 2011.

[4] G.-W. Fan, D.-S. Zhang, D.-Y. Zhai, X.-F. Wang, and L. U. Xin, "Laws and mechanisms of slope movement due to shallowly buried coal seam mining under ground gully," Journal of Coal
Science and Engineering (China), vol. 15, no. 4, pp. 346-350, 2009.

[5] S. S. Peng, Coal Mine Ground Control, Syd S. Peng, Morgantown, Va, USA, 3rd edition, 2008.

[6] M. Qian and P. Shi, Coal Mine Ground Pressure and Control, China University of Mining and Technology Press, 2003.

[7] M. Qian, Key Stata Theory in Strata Control, China University of Mining and Technology Press, Xuzhou, China, 2000.

[8] G. Chen, X. Cheng, W. Chen, X. Li, and L. Chen, "GPS-based slope monitoring systems and their applications in transition mining from open-pit to underground," International Journal of Mining and Mineral Engineering, vol. 5, no. 2, pp. 152-163, 2014.

[9] A. W. Khair, M. K. Quinn, and R. D. Chaffins, "Effect of topography on ground movement due to longwall mining," Mining Engineering, vol. 40, no. 8, pp. 820-822, 1988.

[10] M. Marschalko, I. Yilmaz, M. Bednárik, and K. Kubečka, "Deformation of slopes as a cause of underground mining activities: three case studies from Ostrava-Karviná coal field (Czech Republic)," Environmental Monitoring and Assessment, vol. 184, no. 11, pp. 6709-6733, 2012.

[11] S. S. Peng and Y. Luo, "Slope stability under the influence of ground subsidence due to longwall mining," Mining Science and Technology, vol. 8, no. 2, pp. 89-95, 1989.

[12] D. M. Ross-Brown, "Design considerations for excavated mine slopes in hard rock," Quarterly Journal of Engineering Geology and Hydrogeology, vol. 6, no. 3-4, pp. 315-334, 1973.

[13] R. Singh, P. K. Mandal, A. K. Singh, R. Kumar, J. Maiti, and A. K. Ghosh, "Upshot of strata movement during underground mining of a thick coal seam below hilly terrain," International Journal of Rock Mechanics and Mining Sciences, vol. 45, no. 1, pp. 29-46, 2008.

[14] T. N. Singh and D. P. Singh, "Slope behaviour in an opencast mine over old underground voids," International Journal of Surface Mining \& Reclamation, vol. 5, no. 4, pp. 195-201, 1991.

[15] S. Wang, C. Li, P. Liu, and J. Zhu, "Optimization parameters of the slope under open-underground combined mining," in Transit Development in Rock Mechanics: Recognition, Thinking and Innovation, chapter 41, pp. 229-234, CRC Press, Boca Raton, Fla, USA, 2014.

[16] S. Tu, W. Ma, Z. Wan, and D. Zhang, Experimental Method and Field Measurement on Strata Control, China University of Mining and Technology Press, Xuzhou, China, 2010.

[17] M. D. G. Salamon, "Mechanism of caving in longwall coal mining," in Rock Mechanics Contributions and Challenges, W. A. Hustrulid and G. A. Johnson, Eds., pp. 161-168, A A Balkema Publishers, Golden, Colo, USA, 1990.

[18] D. Zhang, G. Fan, and X. Wang, "Characteristics and stability of slope movement response to underground mining of shallow coal seams away from gullies," International Journal of Mining Science and Technology, vol. 22, no. 1, pp. 47-50, 2012.

[19] G. Fan, Mechanism and Engineering Practice on Mutual Response between Underground Mining of Shallow Coal Seam and Protection of Fragile Ecological Environment, China University of Mining and Technology, 2011. 

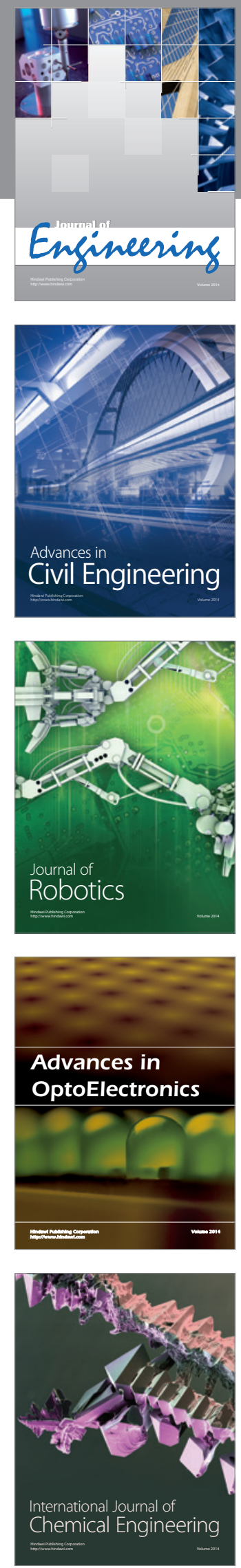

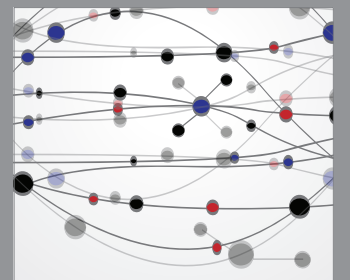

The Scientific World Journal
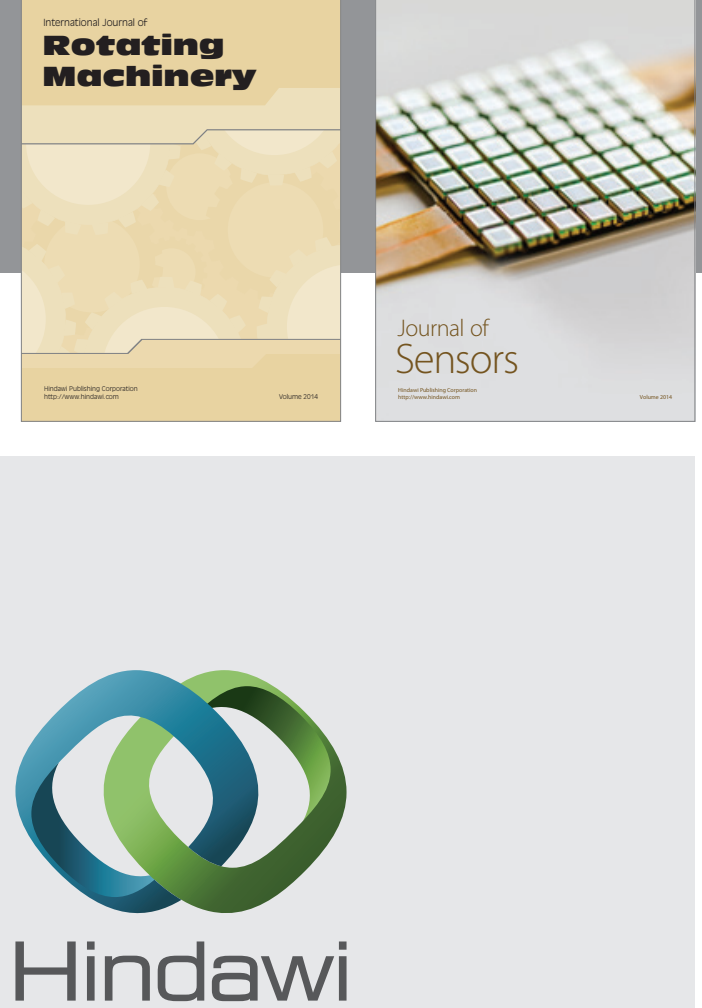

Submit your manuscripts at http://www.hindawi.com
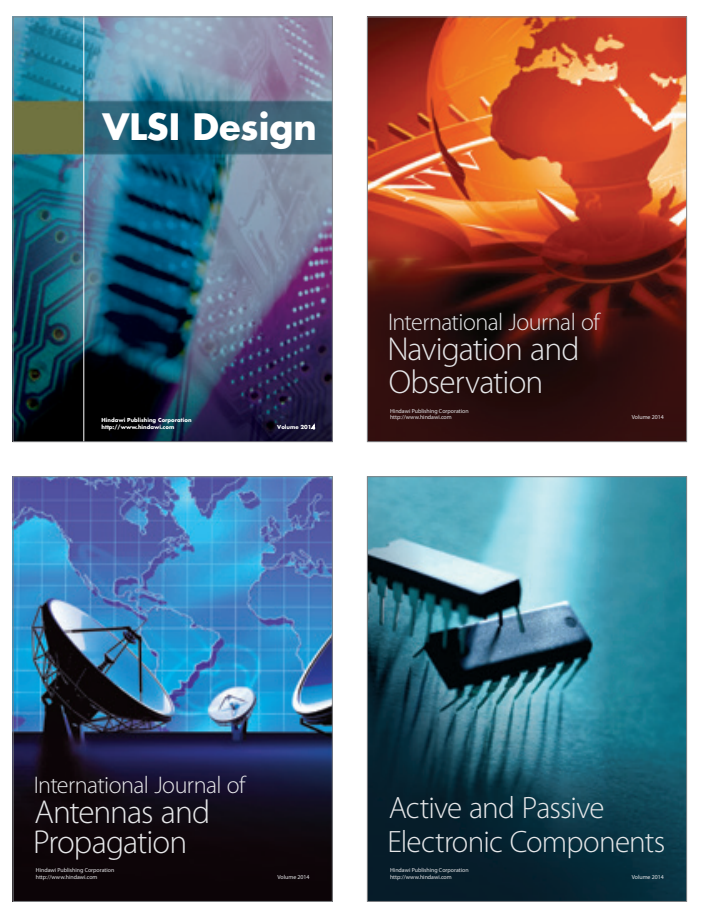
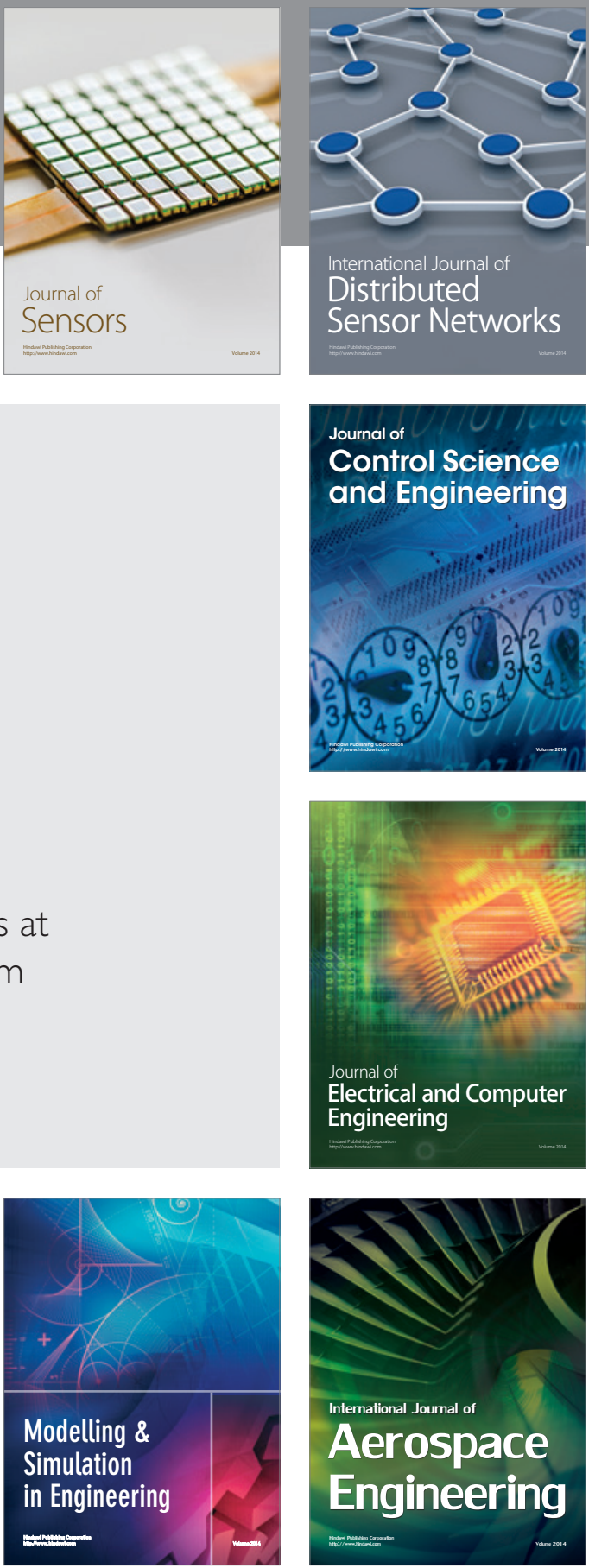

Journal of

Control Science

and Engineering
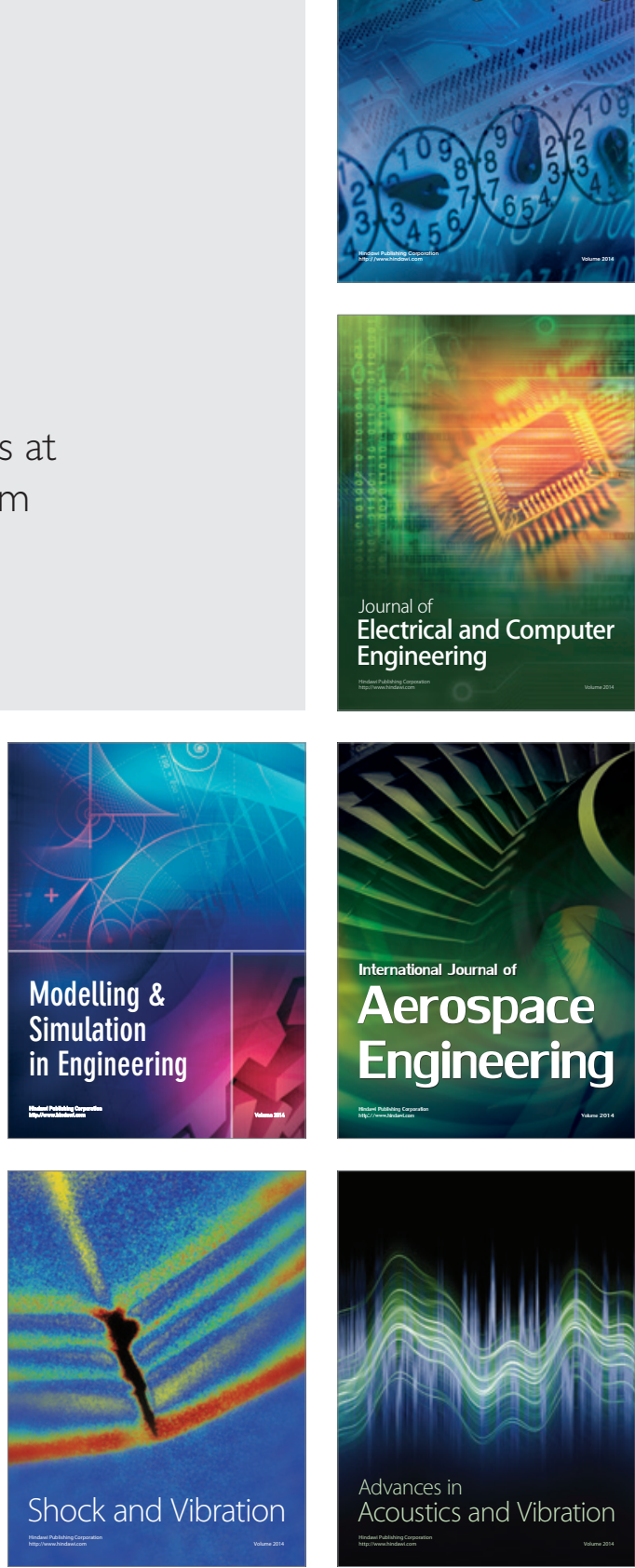